\title{
Partisanship and the gender gap: support for gender quotas in Australia
}

The disparity in the gender gap in parliament between the Australian Labor Party and Liberal Party has grown over time. Katrine Beauregard assesses what measures to increase the representation of women in parliament the public - and political partisans - would support.

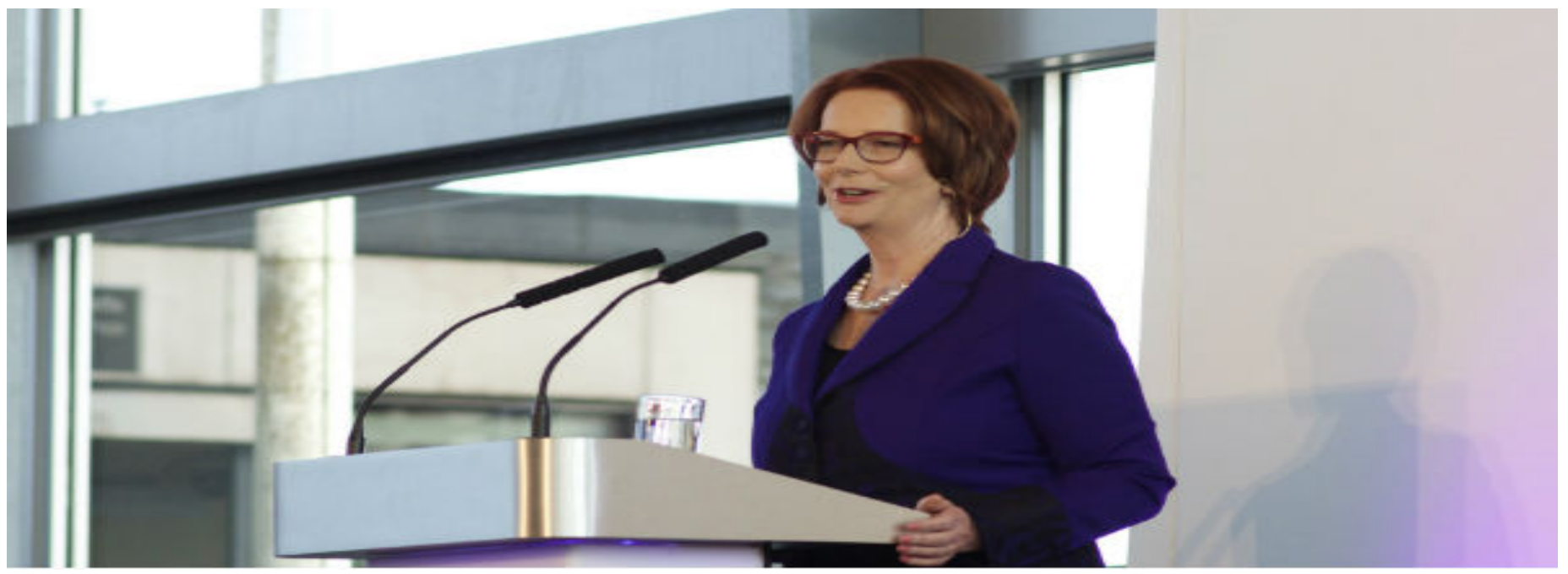

Former Australian Prime Minister Julia Gillard. Picture: National Assembly for Wales, via a_(CC BY 2.0) licence

After the recent by election in Batman, the Australian Labor Party (ALP) made headlines because the party had achieved near gender parity with $48 \%$ of women elected in the Australian Parliament. Discussions of gender division among elected representatives and candidates have also occupied the Liberal Party of Australia (LPA). While aspirational targets have been discussed in the party, some LPA women are taking matters into their own hands, organising special funds for liberal women running for office.

The presence of these debates about women's representation in politics in Australia might be a consequence of a comparatively low percentage of elected women in the legislature. The two main Australian political parties elected a similar percentage of women in the legislature until the early 2000s (Figure 1). After this period, the percentage of women elected under the ALP banner increased at a faster rate than the percentage of Liberal women.

Since the late 1990s and early 2000s, the percentage of Liberal women elected in the House and Senate has remained stagnant. Comparatively, Australia's lower ranking for female representation is, arguably, attributable to the Liberals failing to nominate and elect women. Among established democracies with the highest levels of female representation, Iceland, Sweden, and Finland have over $40 \%$ of women elected in their national legislature; a percentage similar to the ALP.

Figure 1. Percentage of women in federal parliament by party. 


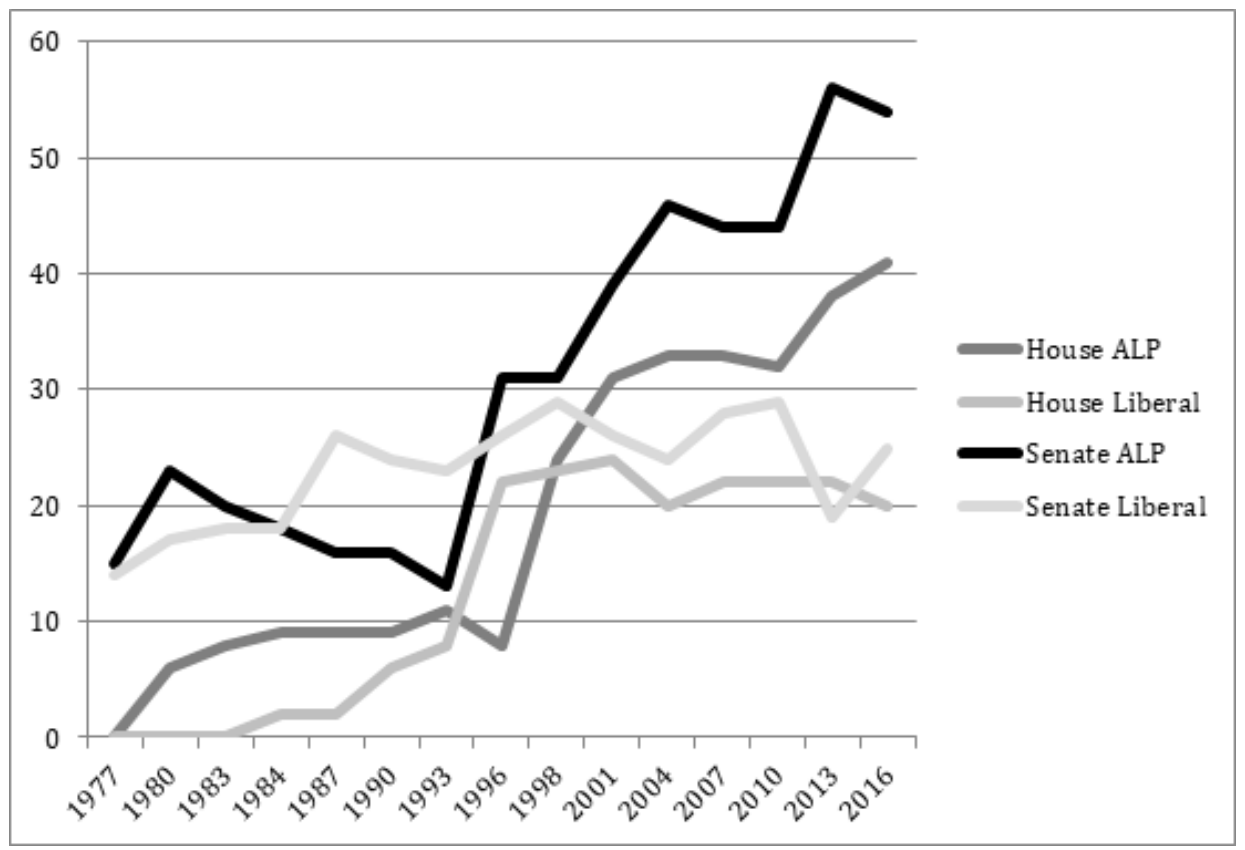

Source: Parliamentary Handbook of the Commonwealth of Australia, multiple years.

The large disparity between both political parties when it comes to the election of women has caused much debate and handwringing about the role of gender quotas in politics. While there seems to be a wide resistance to adopting gender quotas among some politicians and segments of the population, there is little systematic understanding of citizen opinions. Previous research into the adoption of internal political party quotas has demonstrated that parties, particularly those in the centre-right will, be more likely to adopt measures if they believe they might lose votes. Consequently, what voters think is important.

Using the Australian Election Study (AES) conducted in 2016, I investigate the level of support for gender quotas and whether voters believe something should be done to increase the presence of women in politics.

Table 1 shows the distribution of opinion about increasing women's representation by gender. Overall, men tend to think that increasing women's representation is not necessary, while women hold the opposite view. Women are more likely than men to support legislative gender quotas, voluntary party commitments, and encouraging women to participate in politics. All these differences are statistically significant.

Support also varies across different forms of gender quotas. Softer forms of quotas, such as encouraging women to run for office, are more popular among both women and men than party commitments. The least popular is forcing parties to adopt quotas by law. These gender differences are in line with previous international studies of attitudes toward gender quotas.

Table 1. Support for increasing the number of women MPs by gender

$\begin{array}{lccc} & \text { Men } & \text { Women } & \text { Gap } \\ \begin{array}{l}\text { No, there is no need to increase the number of women MPs } \\ \text { No, nothing needs to be done, it will happen naturally }\end{array} & 10.15 & 5.80 & 4.35^{* * *} \\ \begin{array}{l}\text { Yes, by legally requiring all political parties to select more women } \\ \text { candidates by mean of a quota }\end{array} & 91.83 & 28.94 & 12.89^{* * *}\end{array}$


Yes, the political parties should make their own voluntary commitments to increase the number of women MPs

Yes, by encouraging more women to participate in politics

$\mathrm{N}$
17.19 $-4.25^{* *}$

Note: Cell entries are percentages. The gap is calculated by subtracting the percentage of women from the percentage of men Chi-square tests are used to indicate whether gender differences are significant. *: $p<0.05 ;{ }^{* *}: p<0.10 ;{ }^{* * *}: p<0.001$

\section{But how does support vary across parties?}

Figure 2 presents the predicted probability of selecting each category of the question in Table 1 for men and women, first for Liberal partisans, and second, for Labor partisans. The figure shows that there is no difference between women and men for any of the five outcomes for both Liberal and Labor partisans. It also shows that the overall support among Labor partisans for gender quotas is lower than support for 'natural' increases and encouraging women to run for office.

Figure 2. Predicted probability of selecting each outcome for men and women according to partisanship

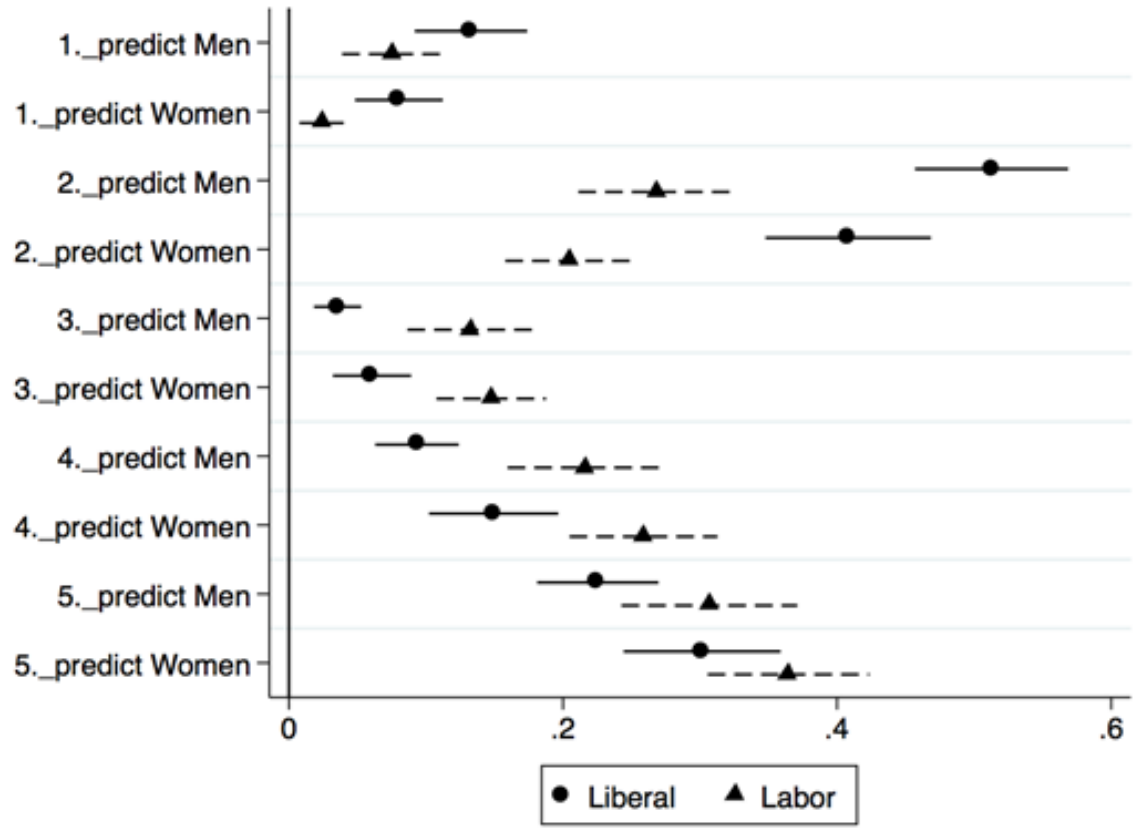

Note: Outcome 1: There is no need to increase the number of women MPs

Outcome 2: Nothing needs to be done, it will happen naturally

Outcome 3: Legally requiring all political parties to select more women candidates

Outcome 4: The political parties should make their own voluntary commitments

Outcome 5: By encouraging more women to participate in politics

A possible explanation for low levels of support for legislative quotas and party measures might be the relatively higher presence of Labor women in the House of Representatives and Senate. Women constitute above $50 \%$ of the ALP senators and above $40 \%$ of ALP representatives. Consequently, Labor partisans might not view policy changes in their party or legislation as necessary to increase the presence of women in politics.

We can see by investigating gender differences in support for gender quotas alongside partisanship, that overall gender differences in support for various types of gender quotas disappear once partisanship is taken into account. 
As political parties are the key actors responsible for adopting gender quotas in established democracies, the lack of significant difference between men and women within political parties indicates that there might be little incentive for parties such as the Liberals to adopt quotas for candidate selection, especially considering that the Liberal Party has enjoyed long-term electoral success.

Consequently, Australia is following an 'incremental track' (as opposed to a 'fast track') when it comes to increasing the presence of women in politics. For an important section of the population, equal representation will be achieved in due course and political parties can increase the percentage of women candidates by increasing their recruitment and training efforts, and not by adopting a fast tract - that is, quotas.

\section{Contagion effect or self-interest?}

The Liberal Party's stalled progress on women's representation demonstrates that they haven't been inspired by Labor's successful adoption of gender quotas. A possible explanation for the lack of a contagion effect might be the absence, until recently, of a gender gap favouring the centre-left political party. This recent change in voting patterns between women and men might indicate that soon the Liberal Party will have to make efforts to attract women from the ALP to maintain its electoral success.

Political parties are pragmatic; if they are convinced that to win elections they need to change their policies regarding the recruitment of women candidates, they will do so. A conversation is already ongoing within the Liberal Party, led by increasingly prominent and powerful women within the party arguing for the adoption of party quotas or targets for candidate selection. Watch this space.

This article represents the views of the author and not those of Democratic Audit. It was first published on Pop Politics Aus and it is based on Partisanship and the gender gap: support for gender quotas in Australia recently published in the Australian Journal of Political Science.

\section{About the author}

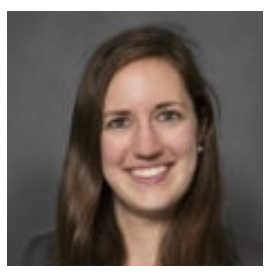

Katrine Beauregard is a Lecturer at the School of Politics \& International Relations, at the Australian National University.

\section{Similar Posts}

- Bedding down, treading water and taking two steps forward: gender equality and the 2019-20 House of Commons select committee elections

- Female parliamentarians still face a motherhood penalty, but the evidence globally suggests it can be ended

- What can political parties do to involve more women in party politics?

- Citizens (mistakenly) perceive female-led political parties as more moderate

- The 'hourglass' pattern of representation: why political parties are key to electing more women to parliament 